\title{
From professors' barriers to \\ organisational \\ conditions in ICT \\ integration in higher education
}

\section{Willy Castro Guzmán}

Professors advisor

Professors advisor in professional develoment for ICT integration in Higher Education. National University, Costa Rica.

\section{Tom Nyvang}

\section{Associate Professor}

Department of Communication and Psychology.
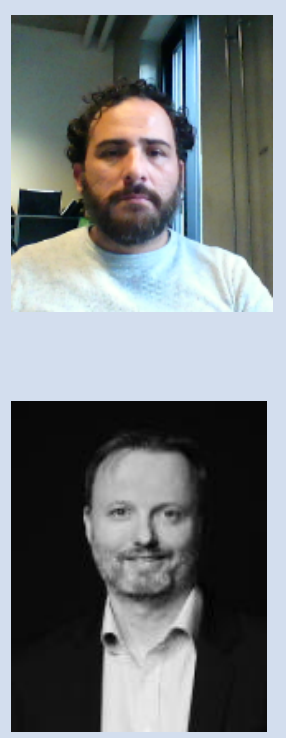

Klik her for at angive tekst. 


\section{Abstract}

The responsibility of innovation with ICT in education has mainly been placed on professors as pivotal to adoption. However, professors are part of complex organisations with inherent obstacles related to their cultural and historical conditions. Despite some studies have stablished the complexity of internal and external barriers separately, others highlight on the importance of considering teachers' beliefs and contextual factors together. In this regard, the article aims to explore the underlying organisational factors affecting professors' adoption and institutional integration of technology, considering the professor as part of the organization. It contributes to the field of limitations and obstacles of ICT adoption, transcending the teachers' barriers approach toward organizational multi-dimensional limitations. The article describes the process of adoption of ICT as non-linear process of discovering barriers and proposing strategies to overcome them. Rather, as a process of development in which solving conflicts can generate other that must be contextually and collectively addressed. The findings contribute to the development of policies and strategies of professional development. The theoretical approach draws upon the cultural-historical activity theory as a tool to transcend the predominant study of barriers from teachers' perceptions and to obtain a comprehensive view of the obstacles restricting the adoption and integration of technology for teaching and learning purposes in higher education.

\section{Abstract in Danish}

Det videnskabelige personale har hidtal haft det centrale ansvaret for iktinnovation i universitetsuddannelser. Det videnskabelige personale indgår i komplekse organisationer med indbyggede forhindringer i form af kulturelle og historiske betingelser. Selvom nogle studier har adskilt interne og eksterne barrierer er der andre, som fremhæver at kontekstuelle betingelser og undervisernes personlige overbevisninger skal betragtes i en sammenhæng. Denne artikel undersøger underliggende organisatoriske faktorers påvirkning af undervisernes adoption, ibrugtagning og institutionelle integration af ikt. Artiklen bidrager til afdækning af begrænsninger og forhindringer for adoption af ikt og bevæger sig fra forståelsen af begrænsninger og forhindringer som knyttet til individdet til at opfatte dem som organisatoriske multidimensionelle begrænsninger. Denne artikel beskriver adoptionsprocessen som en ikkelineær proces med afdækning af barrierer og udvikling af strategier til at omgå dem. Processen opfattes her som en udviklingsproces, der løser konflikter eller ophæver modsætninger mens nye opstår og de må håndteres med blik for konteksten og kollektivt i underviserfællesskaber. Resultaterne bidrager til udvikling af politikker og strategier, der integrerer kompetenceudvikling og ikt-innovation blandt undervisere. Det teoretiske grundlag for artiklen er den kultur-historiske virksomhedsteori, 
der bruges som redskab til at overskride grænserne for de traditionelle studier af barrierer for ikt-innovation i uddannelser og undervisning, og til at opnå et mere helhedsorienteret perspektiv på udfordringer knyttet til at udvikle brugen af ikt i videregående uddannelser.

Rather, as a process of development in which solving conflicts can generate other that must be contextually and collectively addressed. The findings contribute to the development of policies and strategies of professional development. The theoretical approach draws upon the cultural-historical activity theory as a tool to transcend the predominant study of barriers from teachers' perceptions and to obtain a comprehensive view of the obstacles restricting the adoption and integration of technology for teaching and learning purposes in higher education.

Keywords: barriers of ICT integration, information and communication technology, higher education, activity theory.

\section{Introduction}

Nowadays technological resources are crucial to innovation in societies. In education, one of the fundamental challenges is how to take advantage of information and communication technologies (ICT) to improve and transform teaching and learning. In the field, an important part of the debate is about the potential contribution and benefits of technology in students' learning and the call to caution regarding the assertions of technology as a guarantee for success (Voogt \& Knezek, 2008). The field of education and technology has been nourished by the rapid and revolutionary technological developments in society (Murphy \& Rodríguez-Manzanares, 2014), that joined with the omnipresence of ICT (Underwood \& Dillon, 2011) has led towards technologyfocused (Aviram \& Tami, 2004) and teacher-focused (Goktas, Yildirim, \& Yildirim, 2009) approaches. In this scenario, the teacher plays the role of 'the frontier for applying technological innovations to the teaching and learning process' (p. 193).

Lievrouw \& Livingstone (2002), refer to educational technology as the interaction among artefacts, activities and practices, and context. This interaction is not free of obstacles. An approach to understand the obstacles is the theoretical lens of barriers of teachers to ICT adoption. Some studies identify and classify barriers to ICT adoption in education into extrinsic and intrinsic barriers (Ertmer, 1999). Similarly, Pajo and Wallace (2001) refer to personal-attitudinal and organisational barriers, and Becker and Ravitz (2001) separate barriers into environmental and individual categories. Brinkerhoff (2006) divides Ertmer's (1999) first-order barriers into resources, institutional and administrative support, training, and experience, and the second-order barriers into attitudinal and personality-related factors. 
Berge (1998) adds the categories of cultural barriers and technical barriers. Berge considers that faculty members and students from a particular institutional culture affects the particular ways in which the organisation does things. In his study, the cultural changes in the use of technology were difficult but essential to address for teachers and students. Berge argued that changes in the culture of organisations rarely occurs through direct action, and proposed addressing the cultural changes through policies. The influence of culture in the field of technology and education is not limited to organisational culture. Pelgrum (2001) indicates that despite certain common barriers in teachers' perceptions regarding the adoption of technology, there are also important differences caused by specific organisational culture.

Regarding how reseach has approached to barriers in ICT adoption, Al-Senaidi et al. (2009) suggest that research has explored barriers to ICT adoption in education from teachers' perceptions, qualitative approaches (Ertmer, 1999; Guha, 2003; Veen, 1993), and self-developed surveys. Al-Senaidi et al. (2009) discusses the importance of considering the influence of culture on teachers' perceptions. However, using survey approaches is not sufficient to capture the contextual and cultural particularities potentially affecting professors' adoption of technology.

Recognizing the technology potential to benefit teaching and learning, the purpose of this study is to explore how organisational conditions limit professors' adoption of technology in the context of a Costa Rican Higher Education institutions. The study contributes to the corpus of research of limitations in ICT adoption and integration from a collective, socio-cultural approach. We use the cultural-historical activity theory as the framework of analysis to answer the research question: How do particular organisational settings restrain the adoption of ICT for faculty professors at Universidad Nacional, Costa Rica? In the following sections, firstly we review existing literature on the subject and identify a gap in existing research (the lack of a holistic approach to the research of adoption of ICT). Secondly, we propose activity theory as a theoretical framework for researching adoption of ICT that offers a holistic view on the process. Thirdly, we analyse data on adaption with activity theory and finally we conclude on the results regarding the adoption of ICT and the regarding the usefulness of activity theory.

\section{Barriers to ICT adoption}

Research in the last decades has dealt with explaining the complexity and slow integration of technology in education (Buabeng-Andoh Charles, 2012; Groff, J. \& Mouza, 2008), despite the efforts in technological infrastructure and professional development (Tondeur, Van Braak, Ertmer, \& Ottenbreit-Leftwich, 2012). According to Cox, Preston, and Cox (1999), there has been a disappointingly low uptake of ICT. Selwyn (2007) remarks a relatively modest use of technology, and Groff and Mouza (2008) call it a 
disheartening process despite a high investment in technology. Kirkup and Kirkwood (2005) add that, despite the high investment in professional development and development of policies, the results are not yet satisfactory.

The literature has placed much attention on the study of the causes limiting teachers' adoption of technology. Ertmer's seminal work on first and second-order barriers to change (Ertmer, 1999) is a well-accepted approach that describes teachers' perspectives on barriers based on the notion that 'the decision regarding whether and how to use technology for instruction rests on the shoulders of classroom teachers' (Ertmer, 2005, p. 27). Literature on first-order and second-order barriers reveals that the most recurrent first-order type of barriers as the lack of technological resources, the lack or low quality of professional development, the lack of time or excessive workload, the lack of technical support, and the lack of technology integration in the curriculum (Buabeng-Andoh Charles, 2012; Curir, de Romeri, \& Murante, 2010; Mumtaz, 2000). On the other hand, the most recurrent second-order barriers listed are the lack of competencies, skills, or expertise; negative attitudes and beliefs towards technology; teachers' lack of confidence; and resistance to change (Bingimlas, 2009).

From teachers' point of view, the main causes hindering technology adoption are extrinsic to them (Mueller, Wood, Willoughby, Ross, \& Specht, 2008). To Ertmer (1999), the extrinsic limitations are solved to the extent that money is allocated (p. 50). Similarly, Mueller et al. (2008) argue that due to growing technological development, most of the environmental barriers have been eliminated. Furthermore, Prestridge (2012) indicates that the increasing access to ICT, the growing offer of professional development, and development of the curriculum demonstrate that firstorder barriers are being overcome (p. 1).

However, the elimination of first-order barriers does not ensure successful process of adoption. In the African context, Oroma, Kiden, Maghendha, and Ntiyani (2013) a non-consistent frequency of use despite an adequate access to technology. Other studies analysing barriers to technology integration in rich environments shown that once the barrier of lack of technology is overcome, the second largest barrier was the insecurity felt by faculty towards how to integrate it (Schoepp, 2005). This study is consistent with the argument that there is not necessarily a successful adoption when external limitations are overcome (Ertmer, OttenbreitLeftwich, A., York, 2007).

In recent years, the attention has moved toward second-order barriers, or teacher's pedagogical beliefs regarding the use of technology as a key factor in adoption (Tondeur et al., 2012). Mueller et al. (2008) argue that the focus has changed to investigate individual differences in beliefs, attitudes, and skills among teachers. However, after two decades of studies regarding 
barriers to teachers in technology adoption, recent literature shows that the results are not significantly different. Al-Senaidi, Lin, and Poirot (2009) reported lack of equipment, lack of institutional support, disbelief in ICT benefits, lack of confidence, and lack of time as the predominant barriers. Lin, Huang, and Chen's (2014) study of teachers' perception of barriers to ICT adoption in Chinese teaching within US universities identified a lack of financial, peer, and administrative support; insufficient time and equipment; and lack of positive attitudes as the most important barriers to ICT adoption. Raman and Yamat (2014) highlight teachers' hesitancy in integrating ICT, workload, lack of time, teaching experiences and age, and lack of ICT skills. Furthermore, Castro (2016) shows that even professors willing to use technology can experience feelings of frustration in the adoption of technology, causing changes in the behaviour and beliefs of professors in regards to adopting ICT. Willingness is defined by Uju, Chinwe, and Obioma (2015) as the capacity of acting gladly and eagerly in a desirable way. Based on Uju et al. (2015), a willingness in ICT adoption must be understood as the professors' readiness to embrace technology in teaching.

The perceptions (Lin et al., 2014) and voices (Raman \& Yamat, 2014) of teachers are the predominant approaches to the study of the barriers to ICT adoption. This is perhaps one of the reasons why, the lack of organisational change to favour the adoption of technology in the higher education sector has seldom been examined. Organisations need to rethink their organisational innovations (Adel Ben \& Ludovic, 2008). The turn from an individual study of teachers' perceptions of barriers toward an organisational study of conditions for ICT integration demands holistic theoretical and methodological approaches that properly attend to the dichotomy between internal and external barriers (Castro, 2016) and the dichotomy between individual and organisational uses of technology. Moreover, according to Selwyn (2012), research in education and technology must maintain a sense of history and take into consideration multi-level contexts. In the next section, the concepts of the culturalhistorical activity theory used in the study are presented, and how they will be used in the analysis section will be discussed.

\section{Theoretical Framework}

Cultural-historical activity theory (CHAT) is the theoretical framework used in this study. With CHAT, we aim to overcome what we consider a limitation in many studies on barriers, and use teachers' perceptions as the unit of analysis. The unit of analysis in CHAT is the object-oriented activity whose components are the object, subject, mediating artefacts, rules, community, and division of labour (Engeström, 1999). The unit of analysis in the second generation of CHAT is commonly represented in its basic 
form with the complex model of the activity system (AS; Figure 1;

Engeström, 1999).

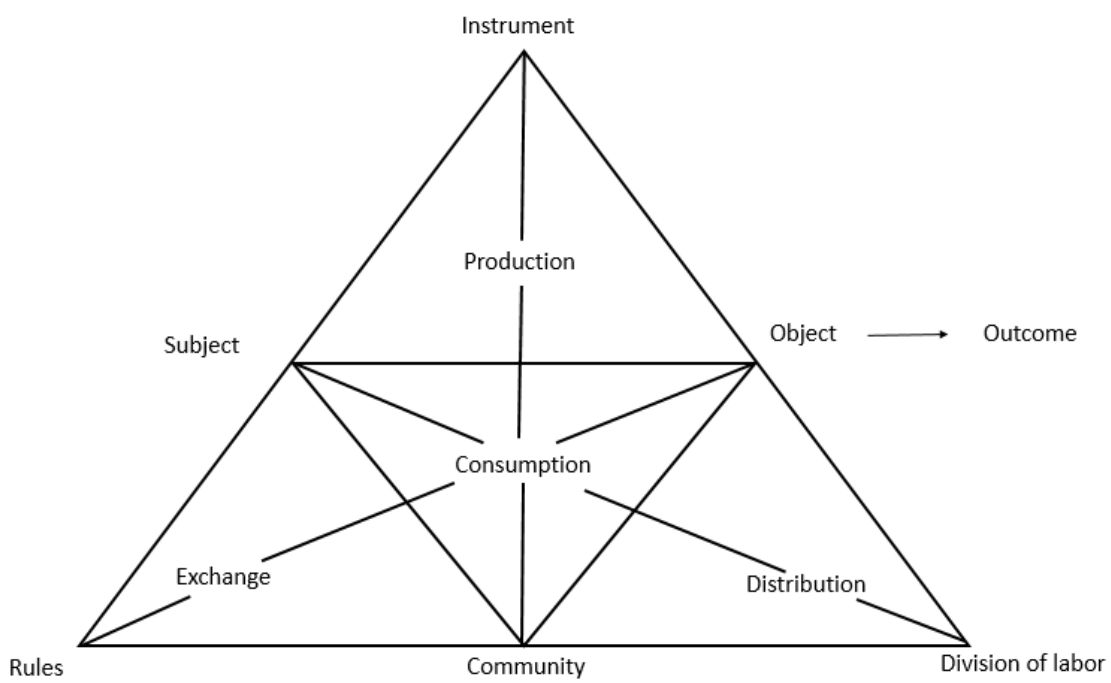

Figure 1 . The model of an activity system as a basic unit of analysis in the second generation of CHAT (Engeström, 2015, p. 63).

Previous studies of barriers considering professors - in the plural-as a unit of analysis is not sufficient to argue that professors are a collective unit of analysis. Within the traditions of CHAT, collectivity does not refer exclusively to an individual or collective subject. Rather, it refers to the complex interrelationships between an individual or collective subject (Davydov, 1999) and the community, respectively (Engeström, 2015). In this study, professors take the place of the subject as the doer of the actions (Hasan \& Kazlauskas, 2014) to achieve an objective or goal in the activity.

According to Engeström (2015), the dominant aspects of human activity are production, distribution, and exchange (Figure 1). The exchange subtriangle (Figure 1); comprises the interactions among the subject, rules, and community of the activity. However, Engeström (2015) indicates that each sub-triangle is potentially an activity of its own (p. 64) that at the same time is formed by the same structure of sub-triangles. Of fundamental importance to the analysis is that the exchange sub-triangle is found inside production, in the form of communication, interaction, and exchange of unfinished products between producers' (Engeström, 2015). The perspective taken in our study is not of isolating the exchange sub-triangle from the complete structure of human activity. It means that the study places primary attention on the three interacting components of exchange.

Regarding the interaction among subjects, rules, and community as the primary focus, it is essential to notice that the subject of the activity can be an individual or group whose viewpoints are adopted in the analysis (Murphy \& Rodríguez-Manzanares, 2014, p. 30). Considering professors as the subject in the activity system has the intention of taking a closer look at 
previous studies on professors' perceptions of barriers. Moreover, the rules refer to 'explicit and implicit regulations' (Engestrom, 1990, p. 79 in Murphy \& Rodríguez-Manzanares, 2014). According to Kuuti (1996), the rules mediate the relationship between the subject and community. The community is described as the social group that the subject belongs to while engaged in an activity (Yamagata-Lynch, 2010, p. 2).

A key concept in activity theory that is also important in the study is contradiction. According to Engeström \& Sannino (2010) contradictions are historically evolving tensions that can be detected and dealt with in real activity systems (p. 4) through their manifestations (Engeström \& Sannino, 2011). There are four types of inner contradictions in CHAT (Engeström, 2015):

- The primary contradiction exists within each component of the activity;

- The secondary contradiction occurs between the components of the activity;

- A tertiary type of contradiction exists between the object in the current activity and the object of the more developed form of activity;

- A quaternary contradiction occurs between the new activity and neighbour activities.

The study is not aimed to find and analyse contradictions in the activity of teaching with technology. A rigorous historical analysis would be necessary to accomplish it. Instead, the intention is to take advantage of the activity system as the unit of analysis to delineate potential secondary tensions, mainly among the professors as the subject in the activity, the resulting rules, and the (other) existing members of the community.

\section{Research Context and Methodology}

This paper reports from an exploratory study carried out with professors at National University (UNA), Costa Rica. The data was collected using a focus group technique. In total five focus group were formed. Three focus groups with professors using technology in their daily teaching practice and two focus groups with professors that at some point have participated in professional development activities for ICT adoption (TPD-ICT). The call for professors to be part of the focus groups was made through the department in charge of promoting the integration of technology at UNA which keeps records of both professors willing to adopt technology and professors participating in TPD-ICT activities. In total, 23 professors were invited and 13 agreed to participate. Moreover, there was no criteria for participants' selection based on the professors' field of knowledge, years of experience, age, gender, or faculty affiliation. Regarding the second type of professors participating in focus groups, those who participated in professional development activities, four lists of courses were requested to 
the Institutional Department of Professional Development. 51 were invited, and one focus group was carried out with four participants. A table summarizing the focus groups configuration is presented (Table 1).

\begin{tabular}{|c|c|c|c|c|}
\hline Type & $\begin{array}{c}\text { Number } \\
\text { of } \\
\text { groups }\end{array}$ & $\begin{array}{l}\text { Participants } \\
\text { per group }\end{array}$ & $\begin{array}{c}\text { Type of } \\
\text { participant }\end{array}$ & $\begin{array}{l}\text { Guiding } \\
\text { topics of } \\
\text { dialogue }\end{array}$ \\
\hline 1 & 3 & $\begin{array}{l}\text { Group } 1=4 \\
\text { Group 2 }=4 \\
\text { Group 3 }=5\end{array}$ & $\begin{array}{l}\text { Professors } \\
\text { using } \\
\text { technology } \\
\text { in teaching } \\
\text { practice }\end{array}$ & $\begin{array}{l}\text { About the } \\
\text { first steps } \\
\text { and } \\
\text { experiences } \\
\text { using } \\
\text { technology } \\
\text { in you } \\
\text { teaching } \\
\text { practice } \\
\text { Opinions } \\
\text { about } \\
\text { integration } \\
\text { technology } \\
\text { in education } \\
\text { at UNA } \\
\text { About } \\
\text { motives to } \\
\text { use ICT in } \\
\text { education } \\
\text { About } \\
\text { limitations } \\
\text { and } \\
\text { enablers in } \\
\text { their own } \\
\text { experience } \\
\text { of ICT } \\
\text { integration } \\
\text { About the } \\
\text { actors } \\
\text { hindering } \\
\text { their } \\
\text { intentions } \\
\text { ICT } \\
\text { integration }\end{array}$ \\
\hline 2 & 2 & Group 1 = 4 & $\begin{array}{c}\text { Professors } \\
\text { that } \\
\text { participated } \\
\text { in TPD-ICT } \\
\text { activities }\end{array}$ & $\begin{array}{c}\text { Opinions on } \\
\text { the process } \\
\text { of ICT } \\
\text { integration at } \\
\text { UNA }\end{array}$ \\
\hline
\end{tabular}




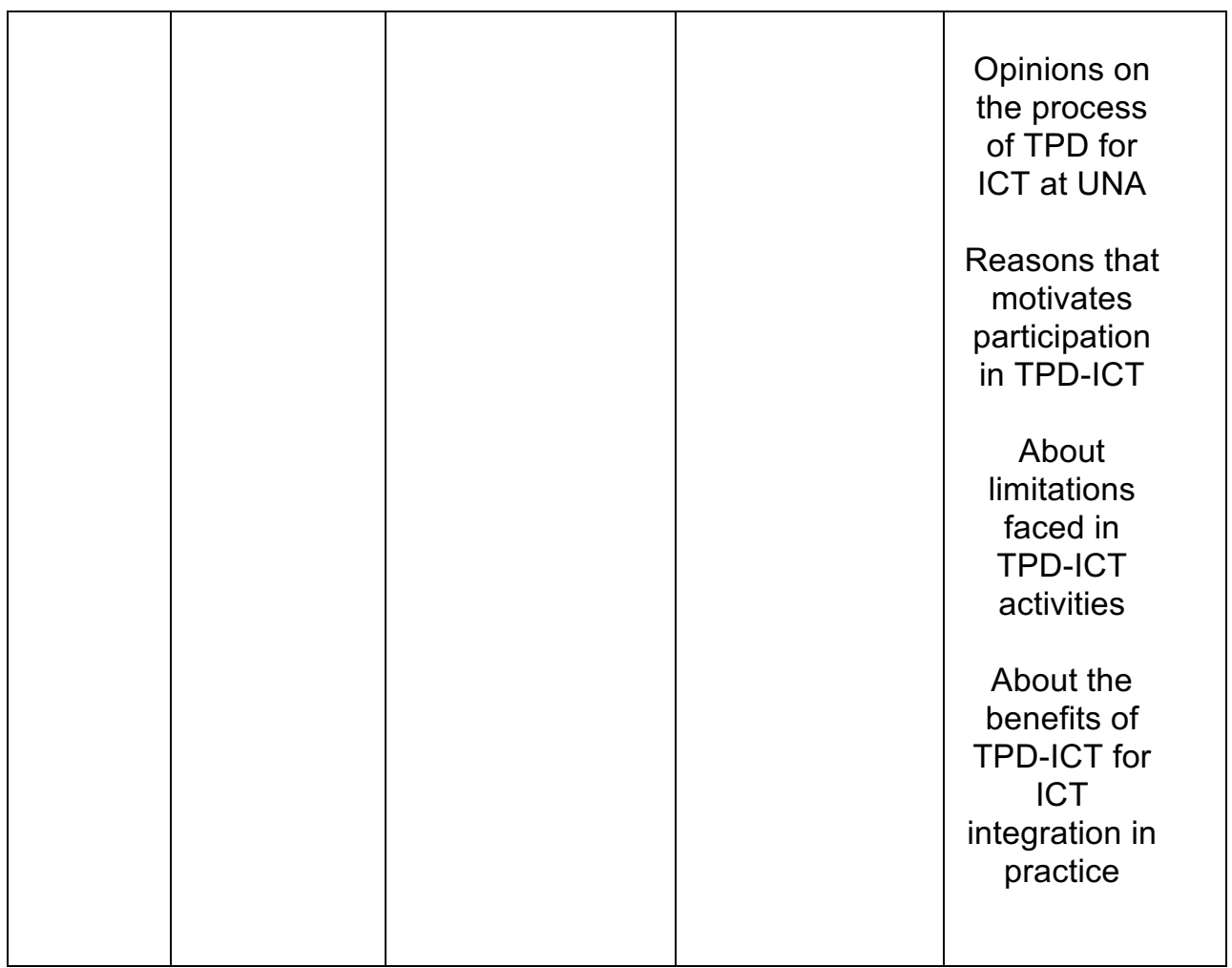

Table1. Summary of the configuration of focus groups in the study.

The focus groups were audio-recorded and transcribed verbatim using the software NVIVO 10. The data were coded and categorised using the constitutive components of the activity system. Each component of the activity system was considered a category. However, the article focus on the rules and the community components of activity theory for the definition of themes. Themes were selected based on the more significant codes matching with the themes found in data and that represent limitations in ICT adoption. In other words, the rules and community members affecting ICT integration and how such affection is explained. In the next sections, we elaborate on the findings.

\section{Findings and Analysis}

In this section, we present the analysis of the dialogue with participants in the focus groups. The professors took the position of the subject in the activity of teaching using technology as a mediator tool. The study shows that professors acknowledge students' learning as the goal of their practice that in turn motivates their use of technology. Since our focus for this paper is not on ICT support for teaching but rather on the organisational context we do not give specific attention to the instrument as a mediator of teaching and learning in this analysis. Instead, our focus will be on the interactions between the subject, professors, rules and members of their community as sources of limitations in their adoption of technology. By doing so we do not disregard the mediating artefact division of labour. Division of labour is inherent in our focus on rules and community. We 
have chosen that analytical path to avoid repetition and improve readability of the analysis.

\section{Regarding the Rules}

In the dialogue, the participants identified both, explicit and non-explicit rules influencing their practice. Explicit rules took the form of formal guidelines coming from the multiple levels of the institution. For instance, middle managers and the University Board. Non-explicit rules took the form of historically and culturally accepted practices.

\section{Explicit Rules}

\section{Academic Freedom}

According to Andreescu (2009), academic freedom is the right of academics to be free from external constraints in teaching and research and to criticise their institutions freely (p. 561). In Universidad Nacional (UNA), academic freedom is a fundamental tenet (Universidad Nacional, 2015, p. 13).

Willing professors considered academic freedom as a limitation in the sense that it grants the right to other professors to deny using technology in teaching practices. The professors with an unfavourable attitude towards technology used academic freedom to support their refusal. The opposite direction of some professors towards technology adoption has effects on professors that aim to use technology, and is an initial obstacle to necessary changes needed to facilitate department integration (e.g., changes in curriculum). In a focus group, T2 explained how her/his colleagues' interpretation of academic freedom affects the integration of ICT in the curriculum:

T2: 'The problem is that among the many freedoms given here [in the University], whether the professor wants to, then he/she does it and whether he/she does not want to, so then no. Our curriculum remains the same. They [the colleagues unwilling to technology] say, I have academic freedom and I will continue to be the professor I want to be'.

However, for other professors, the same rule of academic freedom was acknowledged as positive to the extent that it grants a sense of trust and independence in their work. In other words, they can decide whether and how to adopt the technology. For T8, academic freedom is an enabler instead of a restriction:

T8: 'In the master's program is probably where I have embraced more technology in the classroom and the reason is simple. There, each professor has real academic freedom in the sense that there is a very high trust in faculty. Technology adoption depends on the trust and facilities you have as a professor to develop things'. 
Even though T2 and T8 were professors willing to adopt technology, both had different perceptions on the same rule. While for T8, academic freedom was an enabler, $\mathrm{T} 2$ regarded it as constituting a barrier. In either case it is very much a question and debate concerning division of labor in the community and in the organisation. A high degree of academic freedom also shows potential to freeze the division of labor and prevent change involving coordination between professors.

\section{The Academic Curriculum}

The curriculum is a set of purposeful experiences divided into content, organisation, learning and teaching methods, and assessment (Helsby, 1999 in Knight, 2001, p.369). In university contexts, curriculum is an essential element guiding the tasks of employers, students, and professors (Barnett, Parry, \& Coate, 2001). For the professors who adopted technology, curriculum was perceived as a barrier to adoption. A clear statement about technology in the guidelines related to curriculum has been described in previous studies as an enabler for ICT adoption (Almekhlafi \& Almeqdadi, 2010). Even though professors or academic departments acknowledge the importance of technology in the curriculum to support student learning, the unwilling professors opposed curriculum development. T1 is a professor in the Department of Mathematics who is in charge of training future secondary mathematics teachers. According to T1:

T1: 'Even though the teachers in the high school level have necessities [regarding technology]; my colleagues say: it is not my necessity right now, if the national curriculum changed does not matter to me'.

A static curriculum becomes a weakness for technology integration (Goktas et al., 2009). According to Schoepp (2005), a poor integration of technology in the curriculum is an external barrier for teachers. Overcoming the barrier would require changes in curriculum. However, changes are not an exclusive responsibility of professors willing to adopt technology. Rather, unwilling colleagues' discourses and actions are in opposition to changes in curriculum. Changes in curriculum do not assure resistance-free adoption or integration. T18 told the experience of a fully online program where the curriculum was modified into an online methodology:

T18: 'I see that in general, we could say people [colleagues] have reluctantly accepted the fact that in one way or other they have to teach online courses and cannot be otherwise because this is the way as it is stipulated [in the curriculum], and then if they want to teach here they have to do it in that way'.

The curriculum-related rules affecting the adoption of technology are not issued exclusively at the department level. Rather, administrative departments all over the institution issue the regulations. T6 described 
his/her experience with the institutional department of curriculum about the nature of integration of technology:

T6: 'I had a question about whether the changes from face-to-face to online courses modify or not the nature of the course. They responded to me that it does, but well; I still argue on that. So I disagree that the approval for an online course has to be given by the curriculum department. I would prefer a UNA virtual who is at the same level... In the curriculum department, there is no expert in online learning to make recommendations'.

Once more we identify a struggle regarding division of labor. The professor, T6, disagrees with rules defining who can decide the curriculum and mode of delivery in a course he/she teaches.

\section{Technology-related regulations}

According to Voogt and Knezek (2008) technology is both an object in education and a medium to enhance teaching. Moreover, a material tool that mediates interactions with others and the world that embodies culture improves and transforms human activity (Murphy \& Rodríguez-

Manzanares, 2014, p. 34). The study showed that technology is also a generator of rules. The guidelines issued to regulate the user's interaction with technology can be obstacles to professors' adoption and institutional integration. Technology-related rules are created based on technical criteria. In the case of UNA, the IT department is in charge of the emission of institutional technology-related guidelines. We observed distance between the goals that the IT department aims to achieve with the emission of the technology-related rules and how the rules affect the professors' academic practices and intentions and again we face debate regarding division of labor when it comes to deciding who should be defining the rules of the organisation. The technology-related rules do not necessarily take into consideration the academic necessities. Some technology-related rules induced conflicts between the professors, rules, and IT department. In the following excerpt, T1 explained how the institutional policy on Open Source promoted by the institutional IT department affected their practice of teaching with technology:

T1: 'The problem here [in the University] is that now everything is Open Source and with Open Source, you have to see how to do it, how to adapt all you have learned with another software different to Open Source One, and that brings another type of resistance'.

The lack of technology resources or a deficient performance of technology are both identified as common barriers in the literature (Buabeng-Andoh Charles, 2012). However, the underlying causes of the barriers are complex and rooted not only in the technology itself but in certain norms issued by the IT department. Professor T10 told his experience in this regard: 
T10: We [the academic department] needed approval from... I do not know whom [in IT department]. We did the process, and the purchase was rejected. We were buying the standard two type of computer. So we called them [to IT department] to ask why if we had done the required process? They told us that we do not need standard two computers, that standard one was enough. According to them, there was no reason to buy the standard two even when we sent them a complete explanation about the necessity of running modelling software not running on a standard type of computer'.

As stated, the lack of technology equipment has been accepted as a significant barrier to adoption and a sufficient budget as the correspondent enabler. However, lack of equipment is not necessarily because of the lack of money; rather, institutional rules related to the process of acquiring equipment may limit purchasing.

\section{Administrative rules}

Like technology-based rules, administrative rules at the department and institutional level affect technology adoption and integration. They are created as regulators of administrative aspects of educational practice and are mainly focussed on solving specific problems without considering possible effects in related activities. Rules issued by institutional departments that are not directly related to technology can also affect the adoption and integration of technology. For instance, according to AlSenaidi et al. (2009), lack of time is a barrier to adoption. However, this study showed that limitations of time could be caused by other factors like explicit or non-explicit rules.

\section{Non-explicit rules}

\section{Power relations}

According to Sporn (1996), faculty professors as a university subculture have different values depending on their ambitions. These ambitions can be related to ascending in academic status and salary. The results shown that the integration of technology is also a tool to achieve ambitions and wield power. According to Marginson (1997), power is understood as a repressive force where the possessor of power suppresses the autonomy and individuality of those without power (p. 63). For professors with lower levels of adoption, there exists an exercise of power from colleagues that have higher levels of knowledge, skills, and experience.

The exercise of power in relationships is not unidirectional. Conversely, professors with a degree of knowledge and skill can be both affected by the power of others with higher levels of knowledge and as an agent of power upon others with less knowledge or skills. The relationship with power increases the complexity of decision-making at the department level. The decisions made by groups or individuals under the execution of power 
causes restrictive behaviours, or a form of resistance, in individuals who are affected by the direction of power. For professors interested in the adoption of ICT, the power of a group or an individual with different ambitions derives a lack of movement to change or to further development. T2 reflected on the effect of power on his/her practice:

T2: 'The group having the power is the one who finally decides, and that is not good. If something is liked by the group or by the leader, then it happens. Institutions cannot work in that way'.

When the exercise of power is executed by professors using technology upon those who do not, then an opposite force arises. However, an influential group or individual in academia, administration, or authority can change the direction of adoption. Professors who intend to move to higher levels of adoption are perceived by colleagues or by technology staff as a threat.

\section{Traditions related to field}

Another obstacle to the adoption of technology is the culturally imposed rule on professors and departments regarding the traditions of the field. In previous research, a similar barrier was defined as lack of relevance of ICT to the discipline (Schoepp, 2005). Strong roots in the traditions of the field lead to the idea that it is not necessary to integrate technology. For T2, the situation was common in his/her discipline:

T2: 'In mathematics, professors say that this is the type of mathematics we were taught and that in the next forty years mathematics will be the same. One of the limitations I see is that way of thinking that if during 60 years has been working well, why to change it?'

Pedagogically related practices or beliefs can affect either a group of professors or individuals. For professors willing to adopt technology, it is not worthy to get into conflict with tradition. They overcome an individual level regarding their beliefs about technology, but they see changes in collective beliefs as difficult. T20 referred to his/her experience in the department of music:

T20: 'The case of teaching of music is different; they should use [ICT]. I am not sure if my colleagues apply it. I do not know if they have discovered this tool. In fact, musicians in general are very conservative. It is a pity, but I have noticed. Many [musicians] to change a method, a teaching method is a difficulty, you cannot imagine, so imagine how it is to enter into the digital age'.

\section{The Community of the Willing Professor}

The second focus of attention in the analysis is on the community of professors. This community refers to other individuals or groups in different institutional levels that can restrict professors' adoption of ICT. In 
higher education, the community may include instructors, students, and other institutional personnel (Murphy \& Rodríguez-Manzanares, 2014). In this section, we analyse what members play a role and how these members of the community affect professors' adoption of technology.

\section{Colleagues}

A crucial member of professors' communities is other colleagues.

Colleagues can be teaching the same course or teaching other courses within the curriculum. The integration of technology in a course curriculum by a willing professor could affect other colleagues' work and thus raise discussion regarding division of labor due to the link among courses in the curriculum:

T4: 'If I, as professor of grammar, want to include any technology, the professor of oral expression has to do it as well, maybe the professor of writing as well. In a horizontal level, it has to be a planning process because if you do it at the individual level, it does not work. So, limitations are many, especially in the level of workgroup'.

Professors who have adopted technology on some level are agents affecting both the status and the practice of those professors who are more static regarding technology. According to Toledo (2005), professors can experience different levels of adoption. It makes the process of institutional integration more complex. Professors in higher levels of adoption consider themselves as having adequate pedagogical uses of technology. For them, professors in lower levels of adoption are not necessarily doing so in a proper manner. Professors in lower levels of adoption or with no adoption can express perceptions without any previous experience:

T6: 'And a problem that we have had a lot in school literature is that some professors see online courses or online tools or online teaching as limited to answering email or in some cases worse, only chatting with students'.

\section{The Students}

The students become a significant limitation to adopting technology or to moving into higher levels of adoption or development. Professors using technology acknowledge the potential benefits of ICT for student learning. So, why would students refuse using something that from the beginning seems to be to their advantage? From the professors' perspective, both the students' lack of consciousness and lack of understanding of their role in the learning process with technology are important causes. Some theories have placed the inherent ability and knowledge of technology uses on the students (Bennett, Maton, \& Kervin, 2008; Prensky, 2001). According to professors, cultural, contextual, demographic, or geographical factors influence the levels of experience and the skills of students in technology. Moreover, students' mastering of technology cannot be taken for granted at any educational level. 
T9: 'I have noticed differences among my students from rural zones and from the central area in the sense that I have students that I have to [help] create their email accounts'.

The lack of interaction with technology during the very first levels of a university career is one of the possible reasons for students' limitations. Lacking previous experiences or negative experiences can block the students' willingness towards technology use in learning. There is a tense relationship between teachers and students when experienced professors have some level of technology adoption and non-skilled students. The lack of experience in technical skills and pedagogical appropriation in connection to a weak pedagogical background of students in his/her role through technology leads to a complicated adoption. When the use of technology affects students' grades, they will demand the assistance of the professor in past institutional instances where they had an opportunity to succeed. This pushes professors to limit the uses of technology to avoid problematic situations that could affect their own job. The behaviour of students can be described as dual. They can act as a hindrance to the adoption of technology; however, they also push towards some level of adoption of technology. This can create a tension between students and professors with the former pushing for technology integration and the latter attempting to avoid such integration.

\section{IT Departments}

With the increasing relevance of technology, IT departments were created in organisations to develop and maintenance all technology infrastructure issues. At UNA, there is an institutional IT department and IT staff distributed among the academic departments.

The professors who decided to adopt technology acknowledge the institutional technology department as an important obstacle. These professors do not complain directly about failure in technology, but they point out the responsibility of the department to maintain the proper functioning of the IT infrastructure. For them, the IT department does not execute their job as they should to support professors' teaching activities.

T1: 'At least when I was coordinator of the online program I spent a whole day fighting, not with UNA Virtual, but with CGI because it did not work [internet connection]'.

The IT staff in academic departments are usually specialists in computer science. They do not have a functional relationship with the institutional IT department staff. Instead, they respond to the head of the academic department. They are closer to the professors' daily work. However, they do not have the right profile to respond or attend to their necessities of technology adoption for teaching. 
The technology staff at the department level seems to have an adequate profile to support them because of their physical proximity. However, they lack the knowledge and skills in the specific technologies used by professors. Moreover, they lack understanding in the field of knowledge and pedagogical integration of technology.

\section{Management Level Authorities}

A lack of institutional and administrative support and lack of leadership have been identified as barriers. The head of the department and the faculty dean are the first level of authority influencing professors' work directly. The active participation of department authorities is a critical issue to develop trust in teachers for technology integration. Professors consider that some of the decisions must be made at those levels and that they have an active responsibility in promoting technology adoption. Faculties or departments can have particularities in their internal organisation that are enforced by institutional guidelines and internal requirements. The unidirectional decisions from authorities can have a contrary result to the expected. In one professor's experience, his/her department created the role of a technology coordinator who lead technology integration efforts. However, many reasons such as cultural traits or power relationships can cause the solution to fail in addressing these necessities adequately.

T3: 'What happens is that the person who was coordinating the technological part had never given degree courses, so how that person is going to tell us what to do if you have not had the experience of working with the groups?'

On the other hand, the complexity of institutional organisations strongly affects the decision-making process of authorities on horizontal and vertical organisational dimensions. For instance, rules from the institution's legal department can influence the decisions of academic department authorities. Professors acknowledge the authorities' point of view and their concern to avoid making mistakes and avoid punishment:

T5: 'What I hear from the head of my department is that the legal department says one thing or the comptroller's office says another thing. I do not know if the comptroller's office is what is governing or managing or it is simply that we are afraid when we are making decisions'.

Other factors that can affect authorities' actions to integrate technology are a lack of clear institutional strategy, lack of knowledge on technology, the temporary character of the position of authority, and a lack of time due to an overwhelming set of activities to attend. Moreover, explicit or nonexplicit rules affect authorities' actions (e.g., the culture of fear towards punishment, fear of a negative evaluation, or fear of causing damages from technology). 
The limitations that professors find in authorities also allude to problems in higher levels of management in the university board. An important obstacle is the lack of knowledge and understanding by the members of the board regarding professors' requirements and how to solve them. There is also a lack of direction to give the appropriate instructions to middle-level departments in the emission of basic institutional guidelines.

\section{Discussion}

The findings show that professors are not isolated actors dealing with obstacles in ICT adoption. Moreover, they are not able to control potential variables and deviations from an adequate process of teaching with technology individually. Even though the decision of adopting technology primarily rests on teachers' shoulders (Ertmer, 2005), and is influenced by teachers' beliefs regarding pedagogy and technology, the results show the importance turning attention on the influence of external factors in such decision. Castro (2016) mentions,for instance, the influence of professors' colleagues in ICT adoption or rejection. Although the existence of systemic influences in ICT adoption is recognized, it is yet considered as the professor responsibility the ensure "fit" within their individual teaching context (Ertmer, 1999, p. 48).

Opposite to the studies that emphasise professors' beliefs, or professors' responsibilities of modifying external limitations; this study showed that the decision to start using or to continue using technology, even in professors with positive beliefs toward technology, is influenced by others. These others are individuals or groups in the organisation such as colleagues, authorities, or other departments directly or indirectly related to the integration of technology. Furthermore, institutional guidelines and particular forms of work in the organisation are sources of barriers. Figure 2 depicts the minimal activity system resulting from the study for professors willing to adopt technology for learning. 


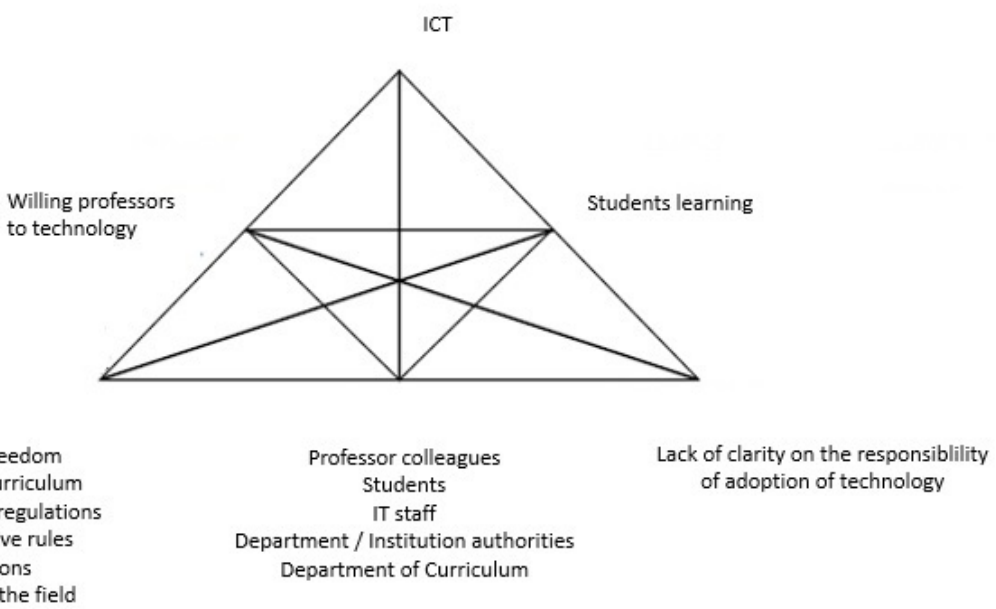

Figure 2. Basic activity system for professors in the activity of teaching with technology (Adapted from Engeström, 2015, p. 63).

It is expected that a professor willing to adopt technology does not experience second-order barriers or can easily overcome potential secondorder barriers. Second-order barriers are, according to Ertmer (1999), the most demanding and crucial to eliminate. It is assumed that once secondorder barriers are overcome, first-order barriers take major relevance. According to some studies, external limitations are overcome by allocating money, infrastructure development, investment in professional development, and development of the curriculum (Ertmer, 1999; Mueller et al., 2008; Prestridge, 2012). However, the study shows the existence of underlying contextual and cultural factors disturbing the allocation of money, infrastructure development, professional development, and the development of the curriculum. Underlying factors can be compared to the section of an iceberg that is not visible from the surface. First-order and second-order barriers from professors' perceptions are merely the tip of the iceberg. The acknowledged detection and resolution of underlying factors or institutional conditions are fundamental for individual ICT adoption and the institutional integration of technology.

The process of finding and overcoming organisational limitations is not linear or common to all the institutions. Conversely, there is complex ecosystem taking part in teaching activity with technology. Barriers are not fixed concepts that assure adoption once they are overcome. On the contrary, institutional limitations are tense or problematic situations whose surpassing can generate further barriers in unexpected forms and with unexpected results. 
The analysis delineates the underlying factors or institutional conditions in the interaction between the professors, members of the community, and explicit and implicit rules influencing professors' adoption of technology. Explicit rules are guidelines or institutional regulations that can influence professors' activities directly or indirectly. On the other hand, non-explicit rules are culturally accepted practices or in some cases a deviation or subjective interpretation of explicit rules. Explicit and non-explicit rules can come from different levels of the organisation, influenced by actors on such levels and by particular institutional cultures or sub-cultures. The underlying factors originated by rules can be classified by Ermert's approach as external to professors, however, not directly attended to by the allocation of money, infrastructure development, or professional development.

Academic freedom, for instance, is acknowledged and internalised by professors as a principle of (division of labor in) higher education. However, the same rule is subjectively interpreted according to professors' purposes as a barrier to ICT adoption or as enablers. In the case of UNA, academic freedom empowers professors to decide whether and how to use technology when the decision does not affect others. When the adoption of technology goes beyond individual adoption in the classroom and affects others in the form, for instance, with changes in the curriculum, academic freedom is a guideline that can also support other colleagues to deny the adoption of technology. Adoption of technology is yet more complex when non-explicit or culturally accepted rules interpreted as the relation of power among professors are considered. The complexity in ICT adoption and integration is bigger when the same rule supports opposite positions, as in the case of academic freedom.

Another relevant example is regarding the exercise of power that can proceed from other actors that take part in the professors' community as colleagues and authorit ies who hinder the adoption of technology. However, in some cases, these power relationships can favour ICT adoption when the one in the power position supports technology. In such a case, unwilling professors and others will be affected. A mutual affection between the professor willing to adopt technology and the members of the community is present. The rules are the mediators of that relationship. Such a relationship makes ICT adoption and integration more complex in the sense that rules are always about one or more members of the community. For instance, difficulties in integrating ICT in instruction and curricula that are not ready to use technology, and ICT that does not fit in to curricula are curriculum-related first-order barriers (Al-Senaidi et al., 2009; Goktas et al., 2009; Pelgrum, 2001; Schoepp, 2005). Professors who become open to technology development in the curriculum is a fundamental step. However, is not possible to change curriculum individually; rather, it is necessary to engage the participation of 
colleagues, internal forms of the organisation in the department, and middle-level departments regarding the curriculum. Whether any of these parts are reluctant to changes in the curriculum, there are formal or informal rules impeding development. A tense situation exists between both parts that use rules as mediators supporting individual positions. This kind of tense situation is an underlying factor causing a lack of development in the curriculum.

Similarly, professors' intentions to adopt technology can be affected by students. If using technology affect students and their grades; an opposite force will come from the student against the use of such technology, even when the aim of using technology is students' learning. Curriculum and power relations are rules mediating the previous example. If the curriculum does not clearly include the use of technology, the students will use it as a tool for complaint. On the other hand, the professor exercise her/his power to push the uses of technology. Additionally, academic freedom and power relations aggravate the tension that exists between willing professors' intentions of using technology and unwilling professors' resistance against using ICT. Further research is necessary to document new tensions or opposite forces between professors and members of the professors' communities. However, what is relevant is to acknowledge the existence of rules and other actors affecting technology adoption, and that there are institutional or organisational conditions that must be attended to in order to facilitate technology adoption. The rules, explicit or not, do not always have a negative connotation. It depends on the point of view of who the rule is acting on. For some professors, the rules are obstacles; for others, the rules support their intentions and actions. The variation is on who occupies the role of the subject in the activity. The relationship of the subject-rules-community indicates that the rules are not isolated components. On the contrary, the rules were created to solve problems in a specific historical moment, and the creators of rules have their reasons for issuing such a rule. In other words, the members of the community have their system of activity.

\section{Conclusions}

This study contributes to expand the study of obstacles experienced by faculty in the adoption of ICT and institutional integration. It calls to transcend the teacher-centred perception as the dominant approach to the study of barriers, and stresses the importance of holistic and multilevel approaches that cover both individual and organisational dimensions and interactions between levels. The study exposes the need to shift from studying barriers experienced in professors' adoption, to the study and creation of institutional conditions for technology integration. It also acknowledges the move from a linear model of overcoming barriers to the continuous process of institutional development of conditions. The study 
does not underestimate the barriers found in previous studies. Conversely, it proposes to expand the framework of analysis for complex contextual realities at work as a form to create developmental solutions.

\section{References}

Adel Ben, Youssef, Ludovic, R. (2008). Uses of Information and Communication Technologies in Europe' s Higher Education Institutions : From Digital Divides to Digital Trajectories *. Revista de Universidad Y Sociedad Del Concimiento, 5, 72-84. https://doi.org/http://dx.doi.org/10.7238/rusc.v5i1.327

Al-Senaidi, S., Lin, L., \& Poirot, J. (2009). Barriers to adopting technology for teaching and learning in Oman. Computers and Education, 53(3), 575590. https://doi.org/10.1016/j.compedu.2009.03.015

Almekhlafi, A. G., \& Almeqdadi, F. A. (2010). Teachers ' Perceptions of Technology Integration in the United Arab Emirates School Classrooms. Educational Technology \& Society, 13(1), 165-175.

Andreescu, L. (2009). Individual academic freedom and aprofessional acts, 59(5), 559-578.

Aviram, R., \& Tami, D. (2004). The impact of ICT on education: the three opposed paradigms, the lacking discourse. Unpublished Manuscript, Beer-Sheva ..., (section 3), 1-45. Retrieved from http://www.reiseducational.org/contenuti/file/ict_impact.pdf

Barnett, R., Parry, G., \& Coate, K. (2001). Teaching in Higher Education Change Conceptualising Curriculum Change. Teaching in Higher Education, 6(4), 435-449. https://doi.org/10.1080/1356251012007800

Becker, H. J., \& Ravitz, J. L. (2001). Computer use by teachers: Are Cuban's predictions correct? In Annual Meeting of the American Educational Research Association (p. 15). https://doi.org/10.1017/CB09781107415324.004

Bennett, S., Maton, K., \& Kervin, L. (2008). The "digital natives" debate: A critical review of the evidence. British Journal of Educational Technology, 39(5), 775-786. https://doi.org/10.1111/j.14678535.2007.00793.x

Berge, Z. (1998). Barriers to online teaching in post-secondary institutions: can policy changes fix it? Online Journal of Distance Learning Administration, 1(2), 1-12. Retrieved from http://www.westga.edu/ distance/ojdla/summer12/berge12.html

Bingimlas, K. A. (2009). Barriers to the successful integration of ICT in 
teaching and learning environments: A review of the literature. Eurasia Journal of Mathematics, Science and Technology Education. https://doi.org/10.1103/PhysRevA.71.032327

Brinkerhoff, J. (2006). Effects of a Long-Duration, Professional Development Academy on Technology Skills, Computer Self-Efficacy, and Technology Integration Beliefs and Practices. Journal of Research on Technology in Education, 39(1), 22-43. https://doi.org/10.1080/15391523.2006.10782471

Buabeng-Andoh Charles. (2012). Factors influencing teachers ' adoption and integration of information and communication technology into teaching : A review of the literature Charles Buabeng-Andoh. International Journal of Education and Development Using Information and Communication Technology, 8(1), 136-155.

Castro, W. (2016). an Activity Theory Approach To Study Barriers of Faculty Regarding Technology Integration in Higher an Activity Theory Approach To Study Barriers of Education, (April), 7232-7241.

Cox, M., Preston, C., \& Cox, K. (1999). What Factors Support or Prevent Teachers from Using ICT in their Classrooms? British Educational Research Association, (1997), 1-23.

Curir, A., de Romeri, V., \& Murante, G. (2010). Evolution and instabilities of disks harboring super massive black holes. Educational Technology Research and Development, 55(3), 223-252. https://doi.org/10.1007/s10509-010-0328-8

Davydov, V. (1999). The content and unsolved problems of activity theory. In Perspectives on activity theory (pp. 39-52). https://doi.org/10.1017/CB09780511812774.004

Engeström, Y. (1999). Activity theory and individual and social transformation. In Perspectives on activity theory (pp. 19-38).

Engeström, Y. (2015). Learning by Expanding (Second Ed.). Cambridge University Press.

Engeström, Y., \& Sannino, A. (2010). Studies of expansive learning: Foundations, findings and future challenges. Educational Research Review, 5(1), 1-24. https://doi.org/10.1016/j.edurev.2009.12.002

Engeström, Y., \& Sannino, A. (2011). Discursive manifestations of contradictions in organizational change efforts. Journal of Organizational Change Management, 24(3), 368-387. https://doi.org/10.1108/09534811111132758

Ertmer, P.A., Ottenbreit-Leftwich, A., York, C. S. (2007). Exemplary 
Technology-Using Teachers: Perceptions of Factors Influencing Success. Journal of Computing in Teacher Education, 23(2), 55-61.

Ertmer, P. a. (2005). Teacher pedagogical beliefs: The final frontier in our quest for technology integration? Educational Technology Research and Development, 53(4), 25-39. https://doi.org/10.1007/BF02504683

Ertmer, P. A. (1999). Addressing first- and second-order barriers to change: Strategies for technology integration. Educational Technology Research and Development. https://doi.org/10.1007/BF02299597

Goktas, Y., Yildirim, S., \& Yildirim, Z. (2009). Main barriers and possible enablers of ICTs Integration into pre-service teacher education programs. Educational Technology and Society, 12(1), 193-204. https://doi.org/Article

Groff, J. \& Mouza, C. (2008). A framework for addressing challenges to classroom technology use. AACE Journal, 16(1), 21-46.

Hasan, H., \& Kazlauskas, A. (2014). Activity Theory: who is doing what, why and how. Being Practical with Theory: A Window into Business Research, 9-14. https://doi.org/10.3102/0034654306298273

Kirkup, G., \& Kirkwood, A. (2005). Information and communications technologies (ICT) in higher education teaching - a tale of gradualism rather than revolution. Learning, Media and Technology, 30(2), 185199. https://doi.org/10.1080/17439880500093810

Knight, P. T. (2001). Complexity and Curriculum : a process approach to curriculum making. Teaching in Higher Education, 6(3), 369-381. https://doi.org/10.1080/1356251012006122

Kuuti, K. (1996). Activity Theory as a Potential Framwork for HumanComputer Interaction Research. In Context and Consciousness: Activity Theory and Human-Computer Interaction (pp. 17-44).

Lievrouw, L. A., \& Livingstone, S. M. (2002). Introduction: The social shaping and consequences of ICTs. Handbook of New Media Social Shaping and Consequences of ICTs.

Lin, C.-Y., Huang, C.-K., \& Chen, C.-H. (2014). Barriers to the adoption of ICT in teaching Chinese as a foreign language in US universities. ReCALL, 26(1), 100-116. https://doi.org/10.1017/S0958344013000268

Marginson, S. (1997). Steering from a distance: Power relations in Australian higher education. Higher Education, 34(1), 63-80. https://doi.org/10.1023/A:1003082922199 
Mueller, J., Wood, E., Willoughby, T., Ross, C., \& Specht, J. (2008). Identifying discriminating variables between teachers who fully integrate computers and teachers with limited integration. Computers and Education, 51(4), 1523-1537. https://doi.org/10.1016/j.compedu.2008.02.003

Mumtaz, S. (2000). Factors affecting teachers' use of information and communications technology: a review of the literature. Technology, Pedagogy and Education, 9(3), 319-342. https://doi.org/10.1080/14759390000200098

Murphy, E., \& Rodríguez-Manzanares, M. A. (2014). Activity Theory Perspectives on Technology in Higher Education. IGI Global. https://doi.org/10.4018/978-1-4666-4590-5

Nacional, U. Estatuto Orgánico (2015).

Oroma, J. O., Kiden, S., Maghendha, M. W., \& Ntiyani, S. (2013). Perspectives on underutilisation of ICT in education in Tanzania, Uganda and Kenya. In 2013 IST-Africa Conference and Exhibition, IST-Africa 2013. IEEE Computer Society. Retrieved from http://www.scopus.com/inward/record.url?eid=2-s2.084893800244\&partnerID=tZOtx3y1

Pajo, K., \& Wallace, C. (2001). Barriers to the uptake of web-based technology by university teachers. The Journal of Distance Education, 16(1), 70-84. Retrieved from http://www.jofde.ca/index.php/jde/article/view/171/127

Pelgrum, W. J. (2001). Obstacles to the integration of ICT in education: Results from a worldwide educational assessment. Computers and Education, 37(2), 163-178. https://doi.org/10.1016/S03601315(01)00045-8

Prensky, M. (2001). Digital Natives,Digital Immigrants Part 1. On the Horizon, 9, 1-6. https://doi.org/10.1108/10748120110424816

Prestridge, S. (2012). The beliefs behind the teacher that influences their ICT practices. Computers and Education, 58(1), 449-458. https://doi.org/10.1016/j.compedu.2011.08.028

Raman, K., \& Yamat, H. (2014). Barriers Teachers Face in Integrating ICT During English Lessons : A Case Study. The Malaysian Online Journal of Educational Technology, 2(3), 11-19.

Schoepp, K. (2005). Barriers to Technology Integration in a TechnologyRich Environment. Learning and Teaching in Higher Educaition, 2(1), 1-24. 
Selwyn, N. (2007). The use of computer technology in university teaching and learning: A critical perspective. Journal of Computer Assisted Learning, 23(2), 83-94. https://doi.org/10.1111/j.13652729.2006.00204.x

Selwyn, N. (2012). Ten suggestions for improving academic research in education and technology. Learning, Media and Technology, 37(3), 213-219. https://doi.org/10.1080/17439884.2012.680213

Sporn, B. (1996). Managing university culture: an analysis of the relationship between institutional culture and management approaches. Higher Education, 32(1), 41-61. https://doi.org/10.1007/BF00139217

Toledo, C. (2005). A Five-Stage Model of Computer Technology Integration Into Teacher Education Curriculum. Contemporary Issues in Technology and Teacher Education, 5, 177-191. Retrieved from http://www.citejournal.org/articles/v5i2currentpractice2.pdf

Tondeur, J., Van Braak, J., Ertmer, P. A., \& Ottenbreit-Leftwich, A. (2012). Understanding the relationship between teachers' pedagogical beliefs and technology use in education: a systematic review of qualitative evidence. Educational Technology Research and Development, 28(5), 425-439. https://doi.org/10.1007/s11423-016-9481-2

Uju, U., Chinwe, O., \& Obioma, U. (2015). Attitude and Willingness of Teachers to the Intergration of Entrepreneurship Education into Secondary School Curriculum in Anambra State. British Journal of Education, Society \& Behavioural Science, 10(1), 1-10. https://doi.org/10.9734/BJESBS/2015/18270

Underwood, J., \& Dillon, G. (2011). Chasing dreams and recognising realities: teachers' responses to ICT. Technology, Pedagogy and Education, 20(3), 317-330. https://doi.org/10.1080/1475939X.2011.610932

Voogt, J., \& Knezek, G. (2008). International Handbook of Information Technology in Primary and Secondary Education. Springer International Handbook of Education (Vol. 20). https://doi.org/10.1007/978-0-387-73315-9

Yamagata-Lynch, L. C. (2010). Activity Systems Analysis Methods. Activity Systems Analysis Methods: Understanding Complex Learning Environments. Boston, MA: Springer US. https://doi.org/10.1007/978-1-4419-6321-5 